\title{
VIRULENSI EMPAT ISOLAT CHILLI VEINAL MOTTLE POTYVIRUS PADA TANAMAN CABAI (CAPSICUM ANNUUM L.)
}

\author{
Ifa Manzila ${ }^{1}$, Sri Hendrastuti Hidayat ${ }^{2}$, Ika Mariska ${ }^{1}$, Sriani Sujiprihati ${ }^{3}$ \\ ${ }^{1}$ Balai Besar Penelitian dan Pengembangan Bioteknologi dan Sumberdaya Genetik Pertanian \\ J1. Tentara Pelajar No.3A Cimanggu Bogor 16114 \\ e-mail: ifa_biogen@yahoo.com \\ ${ }^{2}$ Departmen Proteksi Tanaman, Fakultas Pertanian, Institut Pertanian Bogor, Darmaga, Bogor 16680 \\ ${ }^{3}$ Departmen Agronomi dan Hortikultura, Fakultas Pertanian, Institut Pertanian Bogor, Darmaga Bogor 16680
}

\begin{abstract}
Virulence of Chilli Veinal Mottle Potyvirus isolates on chillipepper (Capsicum annuum L.). Infection of Chilli veinal mottle potyvirus (ChiVMV) has been reported from chilli pepper growing area in Indonesia. Field observation showed wide variation of symptom development starting from mild mottle to severe mottle and vein banding. A research was conducted to study the difference of isolates of ChiVMV collected from West Java (Cikabayan), Central Java (Karadenan), South Kalimantan (Nusa Indah), and West Sumatera (Tanah Datar) based on their response on 10 genotypes of chilli peppers i.e. Jatilaba, Helem, VC246, Keriting Bogor, PBC485, Titisuper, Beauty Bell, Gelora, IPBC Tanjung, and Keriting Sumatera. Each isolates of ChiVMV was mechanically inoculated to each chilli pepper genotype, and observation was conducted every day to record incubation period, symptoms type, and disease incidence. Cikabayan and Nusa Indah isolates were able to infect all chilli pepper genotypes with the shortest incubation period of 3 days in "Tistsuper" and "Beauty Bell" genotypes; whereas Karadenan and Tanah Datar isolates only infected 4 and 6 chilli pepper genotypes, respectively. Although the 4 isolates of ChiVMV showed differences in their host range, but most of them developed similar symptoms ranging from mottle, vein banding, leaf cupping, and malformation. Based on the host response, ChiVMV isolates from Cikabayan and Nusa Indah were considered more virulent than the isolates from Karadenan and Tanah Datar.
\end{abstract}

Key words : Chilli veinal mottle potyvirus, chilli pepper genotypes, virulence

\begin{abstract}
ABSTRAK
Virulensi empat isolat Chilli Veinal Mottle Potyvirus pada tanaman cabai (Capsicum annuum L.). Infeksi Chilli veinal mottle potyvirus (ChiVMV) di daerah sentra tanaman cabai di Indonesia dilaporkan cukup tinggi. Isolat ChiVMV berhasil dikumpulkan dari Jawa Barat (Cikabayan), Jawa Tengah (Karadenan), Kalimantan Selatan (Nusa Indah), Sumatera Barat (Tanah Datar). Pengamatan terhadap gejala infeksi di lapangan menunjukkan adanya variasi gejala yang cukup tinggi, mulai dari belang ringan sampai belang berat yang diikuti dengan penebalan tulang daun. Penelitian tingkat virulensi dilakukan terhadap empat isolat yaitu ChiVMV Cikabayan (Jawa Barat), ChiVMV Nusa Indah (Kalimantan Selatan), ChiVMV Tanah Datar (Sumatera Barat) dan ChiVMV Karadenan (Jawa Tengah), yang memperlihatkan tingkat keparahan gejala yang berbeda. Perbedaan virulensi keempat isolat ChiVMV tersebut selanjutnya dievaluasi berdasarkan kemampuannya menginfeksi 10 genotipe cabai yaitu Jatilaba, Helem, VC 246, Keriting Bogor, PBC 495, Titsuper, Beauty Bell, Gelora, IPBC Tanjung, dan Keriting Sumatera. Masing-masing isolat ChiVMV diinokulasi pada tiap genotipe cabai dengan metode inokulasi mekanis. Pengamatan dilakukan terhadap masa inkubasi, tipe gejala yang muncul, dan kejadian penyakit. Isolat Cikabayan dan Nusa Indah mampu menginfeksi semua genotipe cabai uji dengan masa inkubasi tercepat 3 hari pada genotipe "Titsuper" dan "Beauty Bell"; sementara isolat Karadenan dan Tanah Datar hanya mampu menginfeksi berturut-turut 4 dan 6 genotipe cabai uji. Walaupun ada perbedaan kisaran inang, tetapi variasi gejala yang muncul diantara keempat isolat hampir sama, yaitu mencakup belang, penebalan tulang daun, daun berkerut, dan malformasi. Berdasarkan hal tersebut, ChiVMV isolat Cikabayan dan Nusa Indah diketahui lebih virulen dibandingkan dengan ChiVMV isolat Karadenan dan Tanah datar.
\end{abstract}

Kata kunci : Chilli veinal mottle potyvirus, genotipe cabai, virulensi

\section{PENDAHULUAN}

Beberapa anggota Potyvirus telah dilaporkan dapat menginfeksi tanaman cabai, di antaranya adalah
Chilli veinal mottle potyvirus (ChiVMV). Virus ini pertama kali dilaporkan oleh Burnet pada tahun 1947 menginfeksi Capsicum annuum L. di Malaysia dan dapat menyebabkan penurunan produksi hingga $60 \%$ 
(Ong, 1995). Selanjutnya dilaporkan bahwa virus ini telah menyebabkan penyakit di banyak negara Asia seperti India, Thailand, Taiwan, Korea, Filipina (Ravi et al. 1997; Siriwong et al. 1995; Green, 1991) pada tanaman cabai yang ditanam secara komersial. Di Indonesia, keberadaan ChiVMV telah dilaporkan oleh Duriat et al. (1996), Taufik et al. (2005), Subekti et al. (2006) dan Opriana (2009). Tanaman cabai yang terinfeksi pada daunnya akan memperlihatkan gejala belang-belang hijau gelap, bercak-bercak hijau gelap, dan kadang kadang pola-pola tersebut menyatu ke tulang daun di dekatnya, leaf cupping, epinasti dan nekrosis. Tanaman cabai yang terinfeksi secara umum menjadi kerdil dan mengalami malformasi pada daun. Kadang-kadang buah juga menunjukkan gejala belang-belang atau distorsi sehingga produksi dan kualitasnya menjadi rendah (Ong 1995; Sulyo et al. 1995). Gejala yang disebabkan oleh ChiVMV bervariasi tergantung pada inang, strain virus, waktu infeksi dan kondisi lingkungan. Virus ini dapat ditularkan oleh beberapa spesies kutu daun dan dapat pula ditularkan secara mekanis. Beberapa tanaman yang menjadi inang ChiVMV selain $C$. annuum, adalah $C$. frutescens L., Lycopersicon esculentum Mill., Solanum melongena L., Datura stramonium L., Nicotiana spp., dan Chenopodium spp. (Green et al. 1999).

Penelitian tentang ChiVMV yang telah dilakukan di Indonesia diantaranya berkaitan dengan kajian respon beberapa genotipe cabai terhadap infeksi ChiVMV (Taufik et al.2005), dan pengaruh infeksi ChiVMV terhadap produksi tanaman (Subekti et al. 2006).

Dilaporkan oleh Taufik (2005) bahwa infeksi ChiVMV pada genotipe Cilibangi 6, Helem, Tit Bulat dan Tit Segitiga dapat menurunkan hasil sebesar 68,0\% hingga 98,6\%. Hasil infeksi ChiVMV terhadap pertumbuhan dan hasil tanaman cabai yang dilakukan oleh Subekti et al. (2006) membuktikan bahwa terdapat perbedaan masa inkubasi dan keparahan gejala yang muncul berkaitan dengan sistem ketahanan yang dimiliki oleh tanaman dan tingkat virulensi virus yang menginfeksi. Selain itu infeksi virus menyebabkan bobot buah tiap tanaman berkurang.

Penelitian bertujuan untuk mengetahui virulensi keempat isolat ChiVMV yang berasal dari Jawa Barat, Jawa Tengah, Kalimantan Selatan dan Sumatra Barat pada 10 genotipe cabai (Jatilaba, Helem, VC 246, Keriting Bogor, PBC 495, Titsuper, Beauty Bell, Gelora, IPBC Tanjung, Keriting Sumatera) sebagai upaya untuk melakukan karakterisasi terhadap strain-strain virus yang berbeda.

\section{METODE PENELITIAN}

Penelitian dilakukan di Laboratorium Virologi dan rumah kaca Departemen Proteksi Tanaman, Fakultas Pertanian, Institut Pertanian Bogor dari bulan Juni 2007 sampai dengan Februari 2008. Materi genotipe cabai yang digunakan terdiri atas 10 genotipe cabai yang berasal dari koleksi plasma nutfah Departemen Agronomi dan Hortikultura IPB yaitu Jatilaba, Helem, VC246, Keriting Bogor, PBC495, Titsuper, Beauty Bell, Gelora, IPBC Tanjung dan Keriting Sumatera. Sumber inokulum ChiVMV yang digunakan adalah ChiVMV isolat Cikabayan, Karadenan, Belung, Nusa Indah, Tanah Datar, dan Gayo Barat. Isolat-isolat tersebut berturutturut berasal dari Jawa Barat, Jawa Tengah, Jawa Timur, Kalimantan Selatan, Sumatera Barat, dan Aceh Tengah. Tanaman inang untuk perbanyakan virus adalah tanaman cabai Paprika cv. Beauty Bell.

Pengumpulan dan Perbanyakan Sumber Inokulum. Penelitian diawali dengan tahapan pengumpulan sampel virus. Tanaman cabai yang diduga dan menunjukkan gejala seperti terinfeksi ChiVMV dikumpulkan dari lahan petani pada sentra-sentra produksi cabai. Survei dilakukan pada beberapa tempat di Jawa Barat (4 lokasi), Jawa Tengah (6 lokasi), Kalimantan Selatan ( 13 lokasi), dan Sumatera Barat (2 lokasi). Pengambilan sampel dilakukan dengan hanya mengambil bagian tanaman yang menunjukkan gejala khas ChiVMV. Gejala pada tanaman sampel yang berasal dari lapangan umumnya berupa belang, keriting, ujung daun meruncing dan kerdil. Sampel dari lapangan tersebut selanjutnya dibawa ke laboratorium untuk tahapan deteksi menggunakan teknik DAS-ELISA.

Deteksi ChiVMV menggunakan Metode Double Antibody Sandwich Enzyme Linked Immunosorbent Assay (DAS-ELISA). Deteksi ChiVMV terhadap sampel tanaman yang berasal dari lapangan dan dilakukan dengan metode DAS-ELISA menggunakan 5 jenis antiserum secara terpisah, yaitu terhadap ChiVMV, CMV, PVY, PMMV, dan TMV (DSMZ Germany). Tahapan uji tersebut diawali dengan tahap coating, yaitu sumuran plat mikrotiter (ELISA readerBiorad model 550) diisi dengan $200 \mu$ l antiserum yang telah disuspensikan ke dalam buffer coating (1:1000); dilanjutkan dengan inkubasi plat mikrotiter pada suhu $4^{\circ} \mathrm{C}$ selama semalam. Pada hari berikutnya plat dicuci dengan PBST (phosphate buffer saline tween-20) [8 g NaCl, 0,2 g KH2PO4, 1,15 g Na2HPO4, 0,2 g KCL, $0,2 \mathrm{~g} \mathrm{NaN} 3,5 \mathrm{ml}$ Tween 20, pH 7,4] sebanyak 5 sampai 
7 kali. Daun tanaman bergejala digerus dalam GEB (general extract buffer) [1,3 g Na2SO3, 20 g PVP40, 0,2 g NaN3, $2 \mathrm{~g}$ powdered egg albumin, $20 \mathrm{~g}$ Tween-20, pH 7,4] yang ditambahkan merkaptoetanol $1 \%$ dengan perbandingan 1:10 (b:v). Sap tanaman diambil sebanyak $100 \mu 1$ kemudian dimasukkan kedalam sumuran plat mikrotiter. Plat mikrotiter diinkubasi selama 2 jam pada suhu $37^{\circ} \mathrm{C}$. Plat mikrotiter kemudian dicuci 5 smpai 7 kali dengan PBST, selanjutnya enzim konjugat yang dilarutkan dalam ECL buffer (bovine serum albumin $2 \mathrm{~g}, \mathrm{PVP}-4020 \mathrm{~g}, \mathrm{NaN} 3$ 0,2 g) sebanyak 100 $\mu 1$ dimasukkan ke dalam sumuran dan diinkubasi pada suhu $37^{\circ} \mathrm{C}$ selama 2 jam, kemudian dibilas 5 sampai 7 kali dengan PBST. PNP (P-nitrophenyl-phosphate) yang telah dilarutkan dalam PNP buffer $(0,1 \mathrm{~g} \mathrm{MgCl}$, 0,2 g NaN3, $97 \mathrm{ml}$ dietanolamin), dimasukkan sebanyak $100 \mu \mathrm{l}$ kedalam sumuran plat mikrotiter dan diinkubasikan selama 30 menit sampai 60 menit pada suhu ruang.

Setelah waktu inkubasi tersebut akan terjadi perubahan warna pada cairan di dalam sumuran plat mikrotiter, yaitu warna kuning, yang menandakan reaksi positif. Reaksi segera dihentikan dengan penambahan $3 \mathrm{M} \mathrm{NaOH}$. Selanjutnya nilai absorbansi reaksi dianalisis secara kuantitatif dengan spektrofotometer (Microplate reader $\mathrm{BIO}-\mathrm{RAD}$ Model 550 ) pada panjang gelombang $405 \mathrm{~nm}$. Pengujian dinyatakan positif jika nilai absorbansi sampel uji dua kali nilai absorbansi kontrol negatif.

Virus yang berasal dari sampel tanaman yang memberikan hasil positif hanya terinfeksi ChiVMV, selanjutnya dipropagasi ke tanaman cabai paprika cv. Beauty Bell sebagai tanaman sumber inokulum.

Persiapan Tanaman Uji. Untuk mengetahui tingkat virulensi isolat ChiVMV digunakan sepuluh genotipe cabai yaitu Jatilaba, Helem, Keriting Bogor, PBC 495, Titsuper, Keriting Sumatera, IPBC Tanjung, Gelora, Tegak, dan VC 246 sebagai kontrol tahan. Tanaman uji tersebut disemai dalam baki plastik yang berukuran 30 $\mathrm{cm} \times 24 \mathrm{~cm} \times 5 \mathrm{~cm}$ yang telah diisi dengan media tanam kompos. Masing-masing genotipe ditanamn sebanyak 25 tanaman. Setelah tanaman berdaun dua dipindahkan ke polibag yang berisi tanah gembur dan steril (campuran tanah : pupuk kompos 2:1). Setelah berumur 1 bulan, tanaman siap untuk diinokulasi. Tanaman kemudian dipelihara di rumah kaca kedap serangga dengan pemeliharaan meliputi penyiraman, pemupukan dan penyemprotan insektisida yang dilakukan setiap minggu 1 kali.

Inokulasi Mekanis ChiVMV pada Tanaman Cabai. Daun tanaman terinfeksi ChiVMV yang berasal dari Cikabayan (Jawa Barat), Karadenan (Jawa Tengah),
Nusa Indah (Kalimantan Selatan), dan Tanah Datar (Sumatera Barat) digerus dalam mortar steril yang berbeda. Larutan penyangga fosfat $0,01 \mathrm{M} \mathrm{pH} 7$ ditambahkan dengan perbandingan $1 \mathrm{~g}$ daun terinfeksi virus dalam $5 \mathrm{ml}$ larutan penyangga fosfat $(1: 5 \mathrm{~b} / \mathrm{v})$. Ekstrak tanaman (sap) segera diinokulasikan ke tanaman uji. Setiap tanaman diinokulasi pada 2 helai daun termuda yang telah membuka penuh (30 hari setelah semai). Sebelum diinokulasi diberi karborundum pada bagian atas permukaan daun. Inokulasi dilakukan dengan mengoleskan sap pada permukaan daun secara searah. Segera setelah pengolesan sap dilakukan pembilasan sisa-sisa sap yang masih melekat pada permukaan daun dengan menggunakan air mengalir.

\section{Pengujian Tingkat Virulensi Isolat-isolat ChiVMV.} Sepuluh genotipe cabai digunakan, setelah diinokulasi dengan inokulum ChiVMV yang berbeda secara mekanis (seperti diuraikan sebelumnya). Deteksi juga dilakukan terhadap ChiVMV hasil penularan pada tanaman uji (10 genotipe cabai) lalu diamati. Variabel yang diamati pada kesepuluh genotype cabai uji adalah masa inkubasi (hari), kejadian penyakit (\%), dan jenis gejala yang muncul. Kejadian penyakit dihitung menggunakan rumus $\mathrm{KP}=(\mathrm{n} / \mathrm{N}) \times 100 \%$, dengan $\mathrm{KP}$ adalah kejadian penyakit, $\mathrm{n}$ adalah jumlah tanaman bergejala, dan $\mathrm{N}$ adalah jumlah seluruh tanaman uji.

\section{HASIL DAN PEMBAHASAN}

Pengumpulan Isolat Virus. Sebanyak 25 isolat ChiVMV berhasil dikumpulkan dari beberapa sentra pertanaman cabai, yaitu Jawa Barat, Jawa Tengah, Kalimantan Selatan, dan Sumatera Barat. Sampel tanaman yang dikumpulkan menunjukkan gejala belangbelang hijau gelap, bercak-bercak hijau gelap, kadangkadang pola-pola tersebut menyatu ke tulang daun di dekatnya, leaf cupping, epinasti dan nekrosis. Daundaun yang terinfeksi secara umum menjadi kerdil dan mengalami malformasi. Berdasarkan hasil ELISA menggunakan lima antiserum yang berbeda, infeksi campuran beberapa virus ditemukan pada beberapa lokasi (Tabel 1), sebanyak empat sampel terinfeksi ChiVMV secara tunggal (Tabel 2 ) (mewakili tempat asal isolat) digunakan dalam pengujian virulensi.

Perbanyakan sumber inokulum. Sampel-sampel yang terinfeksi tunggal ChiVMV dan memperlihatkan gejala yang khas dipilih untuk perbanyakan virus di rumah kaca. Empat isolat ChiVMV yang berhasil diperbanyak pada tanaman cabai paprika yaitu isolat Cikabayan (Jawa Barat), isolat Karadenan (Jawa Tengah), isolat Nusa 
Indah (Kalimantan Selatan), dan isolat Tanah Datar (Sumatera Barat). Selanjutnya empat isolat ChiVMV (yang mewakili daerah asal isolat) tersebut digunakan dalam pengujian virulensi isolat pada 10 genotipe cabai. Masing-masing isolat tersebut memperlihatkan respon gejala yang berbeda pada tanaman paprika (Tabel 2). Gejala belang-belang, dan malformasi daun yang berat terlihat pada isolat yang berasal dari Cikabayan, Jawa Barat dan isolat asal Nusa Indah, Kalimantan Selatan. Selain gejala belang pada daun yang khas, isolat Cikabayan dan Nusa Indah juga memperlihatkan gejala terjadinya penebalan tulang daun dan daun menggulung ke atas. Pada dua isolat lainnya yaitu isolat Tanah Datar asal Sumatera Barat dan isolat asal Karadenan, Jawa
Tengah memperlihatkan gejala belang yang ringan (Gambar 1).

Pengujian Virulensi ChiVMV pada Beberapa Genotipe Cabai. Isolat Cikabayan dan Nusa Indah dapat menginfeksi 10 genotipe cabai dengan kejadian penyakit masing-masing antara $20 \%$ sampai $100 \%$ dan 12\% sampai 100\% (Tabel 3 dan 4). Isolat Tanah Datar menginfeksi enam genotipe cabai dengan kejadian penyakit berkisar antara 4\% sampai 68\% (Tabel 5), sedangkan isolat Karadenan hanya menginfeksi empat genotipe cabai dengan kejadian penyakit berkisar antara 32\% sampai 64\% (Tabel 6). Masa inkubasi keempat isolat ChiVMV pada genotipe cabai uji umumnya

Tabel 1. Deteksi virus pada tanaman cabai yang berasal dari beberapa sentra produksi tanaman cabai dengan me tode DAS-ELIS A

\begin{tabular}{lcccccc}
\hline \multirow{2}{*}{\multicolumn{1}{c}{ Asal isolat }} & \multirow{2}{*}{$\begin{array}{c}\text { Jumlah } \\
\text { sampel }\end{array}$} & \multicolumn{5}{c}{ Jumlah sampel yang terinfeksi * } \\
\cline { 5 - 7 } & & ChiVM V & CMV & PM MV & PVY & TMV** \\
\hline Nusa Indah, Kalimantan Selatan & 13 & $6 / 13$ & $1 / 13$ & $0 / 13$ & $0 / 13$ & $1 / 13$ \\
Karadenan, Jawa Tengah & 6 & $3 / 6$ & $1 / 6$ & $0 / 6$ & $0 / 6$ & $1 / 6$ \\
Lembang, Jawa Barat & 4 & $1 / 4$ & $0 / 4$ & $0 / 4$ & $0 / 4$ & $0 / 4$ \\
Tanah Datar, Sumatera Barat & 2 & $2 / 2$ & $0 / 2$ & $0 / 2$ & $0 / 2$ & $0 / 2$ \\
\hline
\end{tabular}

*Jumlah sampel terinfeksi = Sampel yang bereaksi positif (+) dengan DAS - ELISA/total sampel

$* * \mathrm{ChiVMV}=$ Chilli veinal mottle virus; $\mathrm{CMV}=$ Cucumber mosaic virus; $\mathrm{PMMV}=$ Pepper mottle mosaic virus; $\mathrm{PVY}=$ Potato virus $Y$; TMV = Tobacco mosaic virus

Tabel 2. Deskripsi isolat ChiVMV yang digunakan dalam pengujian virulensi

\begin{tabular}{lll}
\hline Kode isolat & Asal isolat virus & ${\left.\text { Gejala pada tanaman perbanyakan virus }{ }^{*}\right)}^{\text {C }}$ \\
\hline \hline CKB & Cikabayan, Jawa Barat & $\begin{array}{l}\text { Belang-belang, penebalan tulang daun dan } \\
\text { malformasidaun yang berat } \\
\text { Belang-belang, malformasi daun yang berat dan } \\
\text { daun mengecil, melengkung keatas }\end{array}$ \\
TD.1 & Nusa Indah, Kalimantan Selatan & $\begin{array}{l}\text { Belang ringan menyebar, tulang daun menebal } \\
\text { dan daun berkerut } \\
\text { Belang ringan, bentuk daun a simetris, daun } \\
\text { mengecildan malformasi }\end{array}$ \\
KR & Kanah Datar, Sumatera B arat &
\end{tabular}

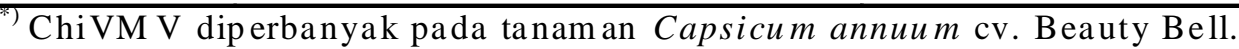
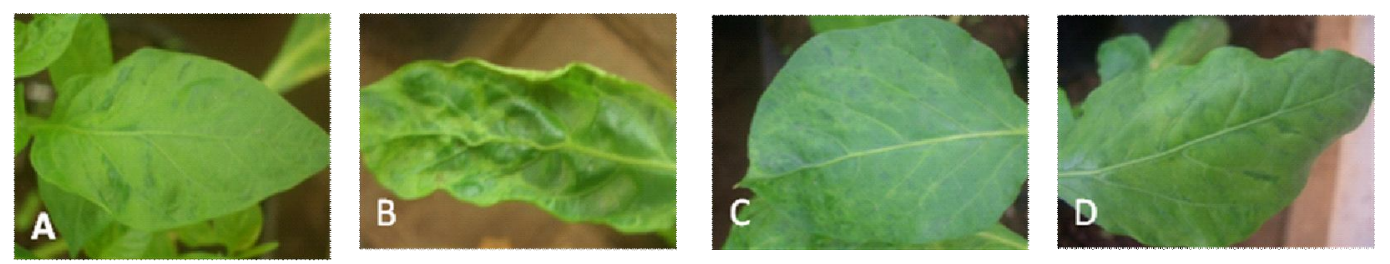

Gambar 1. Variasi gejala infeksi beberapa isolat ChiVMV pada tanaman cabai paprika cv. Beauty Bell. A) Isolat Cikabayan (Jawa Barat); B) Isolat Nusa Indah (Kalimantan Selatan); C) Isolat Tanah Datar (Sumatera Barat); D) Isolat Karadenan (Jawa Tengah). 
berkisar antara 7 hingga 10 hari, tetapi isolat Cikabayan memiliki masa inkubasi yang sangat singkat, yaitu 3 hari, pada varietas Titsuper dan Beauty Bell.

Infeksi keempat isolat ChiVMV pada genotipe yang berbeda memberikan respon yang bervariasi. Walaupun demikian semua isolat ChiVMV menyebabkan gejala belang, penebalan tulang daun, perubahan bentuk daun (malformasi) dan daun berkerut. Gejala daun menggulung tampak jelas pada infeksi isolat $\mathrm{CKB}$, sementara pada isolat lain tidak terlalu jelas. Berdasarkan masa inkubasi, kejadian penyakit, dan gejala yang muncul dapat disimpulkan bahwa keempat isolat memiliki tingkat virulensi yang berbeda. Isolat Cikabayan memiliki tingkat virulensi yang lebih tinggi jika dibandingkan dengan isolat Nusa Indah, Tanah Datar dan Karadenan.

Dilaporkan bahwa infeksi ChiVMV sangat bersifat terbatas, yaitu hanya ditemukan pada pertanaman cabai di Asia dan Afrika (Moury et al. 2005). Penyebaran penyakit belang yang disebabkan oleh ChiVMV pada cabai di Indonesia telah dilaporkan oleh Taufik et al. (2005) yang ditemukan di daerah Pasirwaru Jawa Barat, Bulakparen dan Kresek Jawa Tengah, Gowa, Baraka, Sudu, dan Kalosi Sulawesi Selatan. Pada penelitian ini berhasil diisolasi isolat-isolat ChiVMV yang berasal dari Jawa Barat, Jawa Tengah, Kalimantan Selatan, dan Sumatera Barat sehingga dapat disimpulkan bahwa penyebaran ChiVMV di Indonesia semakin meluas.

Penyebaran penyakit yang semakin luas, dimungkinkan oleh beberapa faktor, di antaranya adalah peranan serangga vektor sebagai agen penular, jenis cabai yang ditanam, dan pola tanam. Serangga vektor yang membantu penyebaran virus tersebut adalah dari kelompok kutu daun (Aphididae: Hemiptera). Diantara spesies kutu daun yang dilaporkan dapat menularkan ChiVMV secara non persisten adalah Aphis craccivora Koch, Aphis gossypii Glover, Aphis spiraecola Patch, Myzus persicae Sulzer, Toxoptera citricidus Kirkaldy, Hystreroneura setariae Thomas dan Ropalosiphum maidis Fitch. Dilaporkan bahwa kutu daun merupakan salah satu serangga hama yang sering ditemukan pada pertanaman cabai di Indonesia (Cahyanto, 2007). Dengan demikian kutu daun memegang peran penting dalam penyebaran ChiVMV di Indonesia. Berdasarkan hasil observasi lapangan, diketahui bahwa jenis cabai yang ditanam di Indonesia umumnya cabai Hot Chilli, Hot Beauty dan Keriting Lokal dengan pola pertanaman sebagian besar monokultur walaupun ada pula yang tumpang sari. Jenisjenis cabai tersebut diketahui sangat rentan terhadap ChiVMV (Millah, 2007) sementara pola tanam monokultur sangat mendukung perkembangan penyakit (Goodman et al. 1986). Areal yang demikian memiliki kecenderungan menjadi daerah endemik bagi penyakit belang pada cabai yang disebabkan oleh ChiVMV.

Empat isolat ChiVMV yang digunakan dalam pengujian (CKB, NI, TD, dan KR) menyebabkan gejala yang bervariasi pada tanaman cabai dengan masa inkubasi yang berbeda-beda. Dijelaskan oleh Agrios (2005) bahwa keparahan gejala yang diakibatkan oleh infeksi virus tergantung pada beberapa hal diantaranya umur tanaman pada saat terinfeksi, lingkungan yang sesuai untuk perkembangan virus, virulensi dari virus yang menyerang tanaman tersebut, serta keberadaan vektor serangga sebagai agen pembawa virus. Virus yang memiliki daya virulensi yang tinggi, mampu melakukan replikasi dengan cepat di dalam sel tanaman (Goodman et al. 1986). Kemampuan virus melakukan replikasi juga ditentukan oleh respon tanaman. Fraser

Tabel 3. Hasil in okulasi ChiVM V isolat Cikabayan pada 10 genotipe cabai

\begin{tabular}{|c|c|c|c|c|}
\hline \multirow{2}{*}{ Genotipe } & \multirow{2}{*}{$\begin{array}{l}\text { M as a Inkubasi } \\
\text { (hari) }\end{array}$} & \multicolumn{2}{|c|}{ Kejadian Penyakit } & \multirow{2}{*}{ Gejala } \\
\hline & & $\mathrm{Ji} / \mathrm{Jn}$ & $\%$ & \\
\hline Ja tilab a & $7-13$ & $25 / 25$ & 100 & $\mathrm{~B} 1, \mathrm{Pt}, \mathrm{M}$ lf \\
\hline Helem & $7-10$ & $17 / 25$ & 68 & Blr,Pt,M lf, Dk \\
\hline VC246 & $8-12$ & $5 / 25$ & 20 & Blr \\
\hline Keriting B ogor & $3-10$ & $25 / 25$ & 100 & $\mathrm{~B} 1, \mathrm{Pt}, \mathrm{Mlf}, \mathrm{Dk}, \mathrm{Mg}$ \\
\hline PBC 495 & $9-14$ & $3 / 25$ & 12 & B $1 r$ \\
\hline Titsuper & $3-9$ & $22 / 25$ & 88 & B 1,Pt,Mlf,Dk \\
\hline Beauty B ell & $3-5$ & $25 / 25$ & 100 & B 1,Pt,Mlf,Dk, Mg \\
\hline Gelora & $7-10$ & $18 / 25$ & 72 & $\mathrm{~B} 1, \mathrm{Pt}, \mathrm{Mlf}, \mathrm{Dk}$ \\
\hline IPBC Tanjung & $4-7$ & $25 / 25$ & 100 & $\mathrm{~B} 1, \mathrm{Pt}, \mathrm{M}$ lf, Dk \\
\hline Keriting Sumatera & $9-12$ & $5 / 25$ & 20 & Blr,Mg \\
\hline
\end{tabular}

$\mathrm{Ji}=\mathrm{Jumlah}$ tanaman berg ejala; Jn = Jumlah tanaman yang diinokulasi; Bl = Belang, Blr = Belang ringan; $\mathrm{Dk}=\mathrm{Dau}$ berkerut $\mathrm{Pt}=$ Penebalan tulang daun; $\mathrm{Mlf}=$ Malformasi $; \mathrm{Mg}=$ Menggulung 
Tabel 4. Hasil in okulasi ChiVM V isolat Nusa Indah pada 10 genotipe cabai

\begin{tabular}{|c|c|c|c|c|}
\hline \multirow{2}{*}{ Genotipe } & \multirow{2}{*}{$\begin{array}{c}\text { Masa Inkubasi } \\
\text { (hari) }\end{array}$} & \multicolumn{2}{|c|}{ Kejadian Penyakit } & \multirow{2}{*}{ Gejala } \\
\hline & & $\mathrm{Ji} / \mathrm{Jn}$ & $\%$ & \\
\hline Jatilab a & $9-13$ & $25 / 25$ & 100 & Blr, Dk \\
\hline Helem & $7-10$ & $17 / 25$ & 68 & Blr \\
\hline V C246 & $10-13$ & $5 / 25$ & 20 & Blr \\
\hline Keriting B ogor & $7-10$ & $25 / 25$ & 100 & $\mathrm{Bl}, \mathrm{Pt}, \mathrm{Mg}$ \\
\hline РBC 495 & $10-13$ & $3 / 25$ & 12 & Blr \\
\hline Titsuper & $7-9$ & $22 / 25$ & 88 & $\mathrm{Blr}, \mathrm{Pt}$ \\
\hline Beauty B ell & $6-7$ & $21 / 25$ & 84 & $\mathrm{Bl}, \mathrm{Pt}, \mathrm{M} 1, \mathrm{Dk}$ \\
\hline Gelora & $9-10$ & $18 / 25$ & 72 & $\mathrm{Bl}, \mathrm{Dk}$ \\
\hline IPBC Tanjung & $7-9$ & $22 / 25$ & 88 & Blr \\
\hline Keriting Sumatera & $9-12$ & $5 / 25$ & 20 & Blr \\
\hline
\end{tabular}

$\mathrm{Ji}=\mathrm{Jumlah}$ tanaman bergejala; Jn = Jumlah tanaman yang diinokulasi; Bl = B elang, Blr = Belang ringan; Dk = Daun berk erut; $\mathrm{Pt}=$ Penebalan tulang dau $; \mathrm{Mg}=\mathrm{m}$ eng gu lung

Tabel 5. Hasil in okulasi ChiVM V isolat Tanah Datar pada 10 genotipe cabai

\begin{tabular}{lcccc}
\hline \multirow{2}{*}{ Genotipe } & $\begin{array}{c}\text { Masa Inkubasi } \\
\text { (hari) }\end{array}$ & Ji/Jn & $\%$ & Gejala \\
\cline { 3 - 4 } & $9-13$ & $10 / 25$ & 40 & Blr, Dk, Mg \\
Jatilaba & $9-10$ & $15 / 25$ & 60 & Blr,Mlf,Pt \\
Helem & 0 & $0 / 25$ & 0 & Ti \\
VC246 & $9-12$ & $11 / 25$ & 44 & Bl,Mlf,Pt \\
Keriting B ogor & $10-12$ & $1 / 25$ & 4 & Blr \\
PBC495 & $9-10$ & $17 / 25$ & 68 & Blr \\
Titsuper & 9 & $17 / 25$ & 68 & Bl,Mlf,Pt,Dk \\
Beauty B ell & 0 & $0 / 25$ & 0 & Ti \\
Gelora & 0 & $0 / 25$ & 0 & Ti \\
IPBC Tanjung & 0 & $0 / 25$ & 0 & Ti \\
Keriting Sumatera & & &
\end{tabular}

$\mathrm{Ji}=$ Jum lah tanaman bergejala; Jn = Jumlah tanam an yang diinokulasi; Ti = Tanaman tidak terinfeksi; $\mathrm{Bl}=$ Belang, $\mathrm{Blr}=$ Belang ringan; $\mathrm{Dk}=\mathrm{Daun}$ berkerut; $\mathrm{Pt}=$ Penebalan tulang daun; $\mathrm{Mlf}=$ Malformasi; $\mathrm{Mg}=$ meng gu lung

Tabel 6. Hasil inokulasi ChiVM V isolat Karadenan pada 10 gen otipe cabai

\begin{tabular}{|c|c|c|c|c|}
\hline \multirow{2}{*}{ Genotipe } & \multirow{2}{*}{$\begin{array}{c}\text { Masa Inkubasi } \\
\text { (hari) }\end{array}$} & \multicolumn{2}{|c|}{ Kejadian Penyakit } & \multirow{2}{*}{ Gejala } \\
\hline & & $\mathrm{Ji} / \mathrm{Jn}$ & $\%$ & \\
\hline Jatilab a & $9-10$ & $10 / 25$ & 40 & Blr, Dk \\
\hline Helem & 0 & $0 / 25$ & 0 & $\mathrm{Ti}$ \\
\hline VC246 & 0 & $0 / 25$ & 0 & $\mathrm{Ti}$ \\
\hline Keriting B ogor & $12-13$ & $8 / 25$ & 32 & Blr \\
\hline PBC 495 & $\operatorname{Tr}$ & $0 / 25$ & 0 & $\mathrm{Ti}$ \\
\hline Titsuper & $9-10$ & $16 / 25$ & 64 & $\mathrm{Bl}$ l,Pt,Mlf \\
\hline Beauty B ell & $9-10$ & $15 / 25$ & 60 & $\mathrm{Bl}, \mathrm{Pt}, \mathrm{Mlf}$ \\
\hline Gelora & 0 & $0 / 25$ & 0 & $\mathrm{Ti}$ \\
\hline IPBC Tanjung & 0 & $0 / 25$ & 0 & $\mathrm{Ti}$ \\
\hline Keriting Sumatra & 0 & $0 / 25$ & 0 & $\mathrm{Ti}$ \\
\hline
\end{tabular}

Ji = Jumlah tanaman bergejala; Jn = Jum lah tanaman yang diinokulasi; Ti = Tanaman tidak terinfeksi; $\mathrm{B} 1=$ Belang, Blr = Belang ringan; $\mathrm{Dk}=\mathrm{Daun}$ berkerut; $\mathrm{Pt}=$ Penebalan tulang daun; $\mathrm{Mlf}=$ Malformasi 
(1998) menyatakan bahwa tanaman yang imun dicirikan oleh ketidakmampuan virus untuk bermultiplikasi sehingga gejala tidak terjadi, sedangkan tanaman yang tahan dicirikan oleh kemampuan tanaman untuk membatasi perkembangan virus dalam sel tertentu sehingga virus tidak menyebar ke sel-sel yang lain (Matthews 2002). Tanaman yang toleran terhadap virus adalah tanaman yang masih dapat terinfeksi, tetapi memiliki kemampuan bertahan terhadap keberadaan dan multiplikasi virus yang dapat ditunjukkan dengan berkurangnya gejala penyakit dan mampu membatasi kehilangan hasil (Keller et al. 2000). Selanjutnya peneliti yang sama menyatakan bahwa tanaman dikatakan rentan apabila tanaman tidak memiliki kemampuan untuk mengatasi invasi virus sehingga muncul gejala yang jelas sebagai akibat terjadinya replikasi virus yang tinggi

Pada penelitian ini diketahui bahwa keempat isolat ChiVMV memiliki kemampuan menginfeksi genotipe Jatilaba, Titsuper dan Beauty Bell dengan kejadian penyakit berkisar antara $40 \%$ sampai $100 \%$ dan menyebabkan gejala cukup parah. Dengan demikian ketiga genotipe tersebut tergolong genotipe yang rentan sedangkan genotipe lain seperti VC 246, PBC 495, Gelora, IPBC Tanjung dan Keriting Sumatera adalah genotipe yang memiliki respon terhadap masa inkubasi yang lebih panjang yaitu 9 hingga 12 hari dengan kejadian penyakit cukup rendah yaitu $0 \%$ sampai $12 \%$. Oleh karena itu genotipe-genotipe tersebut dapat digolongkan kedalam genotipe yang tahan dan dapat ditanam di daerah spesifik isolat tertentu.

Dengan terdeteksinya ChiVMV pada pertanaman cabai di beberapa daerah di Jawa Barat, Jawa Tengah, Kalimantan Selatan, dan Sumatera Barat, maka penelitian yang lebih mendetail mengenai hubungan tingkat virulensi dan keragaman genetik virus perlu dilakukan. Informasi yang diperoleh tentang keragaman genetik dari isolat-isolat ChiVMV perlu dikaji lebih lanjut, untuk memperoleh gambaran tentang keragaman genetik dari isolat-isolat ChiVMV di Jawa, Kalimantan, dan Sumatera sebagai upaya didalam menentukan strategi pengendaliannya.

\section{SIMPULAN DAN SARAN}

ChiVMV telah terdapat di beberapa daerah penanaman cabai di Jawa Barat, Jawa Tengah, Kalimantan Selatan, dan Sumatera Barat. Isolat ChiVMV memiliki kisaran inang dan masa inkubasi yang beragam. Isolat Cikabayan dan Nusa Indah mampu menginfeksi 10 genotipe cabai uji dengan masa inkubasi tercepat 3 hingga 6 hari pada genotype "Titsuper" dan
"Beauty Bell"; sementara isolat Keradenan dan Tanah Datar hanya mampu menginfeksi berturut-turut 4 dan 6 genotipe cabai uji dengan masa inkubasi rata-rata 9 hingga 12 hari. Isolat Cikabayan dan Nusa Indah memiliki tingkat virulensi lebih tinggi dibandingkan isolat Tanah Datar dan Karadenan berdasarkan kejadian penyakit, masa inkubasi, dan gejala.

Berdasarkan hasil penelitian diketahui bahwa tiga genotipe yaitu Jatilaba, Titsuper dan Beauty Bell bersifat sangat rentan terhadap keempat isolat ChiVMV. Oleh karena itu ketiga genotipe tersebut tidak disarankan untuk ditanam di daerah endemik ChiVMV. Sebaliknya tujuh genotipe yang lain yang memiliki respon tahan terhadap isolat ChiVMV tertentu, dapat disarankan untuk ditanam di daerah-daerah tertentu. Sebagai contoh genotipe VC246 tahan terhadap ChiVMV isolat Tanah Datar dan Karadenan dapat dianjurkan di tanam di daerah Sumatera Barat dan Jawa Tengah.

\section{UCAPAN TERIMA KASIH}

Penulis mengucapkan terima kasih dan penghargaan yang sebesar-besarnya kepada Badan Litbang Pertanian dan Pimpinan Proyek Kerjasama Kemitraan Penelitian Pertanian dengan Perguruan Tinggi (KKP3T) atas dukungan dana untuk melakukan penelitian.

\section{DAFTAR PUSTAKA}

Agrios GN. 2005. Plant Pathology. Ed ke-5. New York: Elsevier Academic Press.

Cahyanto Y. 2007. Tingkat serangan kutu daun Aphis gossypii(Glov.) (Hemiptera: Aphididae) pada enam genotype cabai (Capsicum annuum L.) di Bogor [skripsi]. Institut Pertanian Bogor.

Duriat AS. 1996. Cabai merah: Komoditas Prospektif dan Andalan. Hal. 1-3 Di dalam: Duriat AS, Widjaja W. Hadisoeganda A, Soetiarso TA dan Prabaningrum L. Teknologi Produksi Cabai Merah. Pusat Penelitian dan Pengembangan Hortikultura, Badan Penelitian dan Pengembangan Pertanian.

Fraser RSS. 1998. The Genetic of Plant Virus Interaction Implication for Plant Breeding. Euphytica 63:175-185

Goodman RN, Kiraly Z, Wood KR. 1986. The Biochemistry and Phyisiology of Plant Disease. Columbia: University of Missouri Press.

Green SK. 1991. Guidelines for diagnostic work in plant virology. ARDC technical bulletin $15.63 \mathrm{p}$. 
Green SK, Hiskias Y, Lesemann DE, Vetten HJ. 1999. Characterization of Chilli veinal mottle virus as a potyvirus distinct from pepper veinal mottle virus. Petria 9, 332.

Hull R. 2002. Matthews 'Plant Virology'. Fourth Ed, San Diego: Academic Press

Keller B, Feuillet, Messmer. 2000. Genetic of disease resistance. Pp. 101-160 In: Slusarenko A, Fraser RSS \& van Loon LC. Mechanism of Resistance to Plant Disease. Kluwer Academic Publishers.

Marco S, Cohen. 1979. Rapid detection and titer evalution of viruses in pepper by enzyme-linked immunosorbent assay. Phytopathology 69:12591262

Matthews REF. 2002. Plant Virology. Academic Press. San Fransisco.

Millah Z. 2007. Pewarisan karakter ketahanan tanaman cabai terhadap infeksi Chilli veinal mottle virus [tesis]. Bogor, Sekolah Pascasarjana, IPB.

Moury B, Palloix A, Caranta C, Gognalons P, Souche S, Sellassic KG, Marchoux G. 2005. Serological, molecular, and pathotype diversity of pepper veinal mottle virus and Chilli veinal mottle virus. Phytopathology 95:227-232.

Ong CA. 1995. Symptomatic variants of CVMV in Malaysia. Proceeding of the AVNET II Midterm Workshop Philippines 21-25 Februari 1995. AVRDC.
Opriana E. 2009. Metode deteksi untuk pengujian respon ketahanan beberapa genotype cabai terhadap infeksi Chilli veinal mottle potyvirus (ChiVMV) [tesis]. Bogor, Sekolah Pascasarjana, IPB.

Ravi KS, Joseph J, Nagaraju N, Krishna PS, Reddy HR, Savithri HS. 1997. Characterization of a pepper vein banding virus from chilli pepper in India. Plant Dis. 81:673-676

Siriwong P, Kittipakorn K, Ikegami M. 1995. Characterization of chilli vein-banding mottle virus isolated from pepper in Thailand. Plant Pathology 44: 718-727

Subekti D, Hidayat SH, Nurhayati E, Sujiprihati S. 2006. Infeksi cucumber mosaic virus dan chilli veinal mottle virus terhadap pertumbuhan dan hasil tanaman. Hayati 13:53-57

Sulyo Y, Duriat AS, Gunaeni N, Korlina E. 1995. Determination of CMV and CVMV strains in Indonesia. Proceeding of the AVNET II Midterm Workshop Philippines 21-25 Februari 1995. AVRDC.

Taufik M, Astuti AP, Hidayat SH. 2005. Survey infeksi cucumber mosaic virus dan chilli veinal mottle virus pada tanaman cabai dan seleksi ketahanan beberapa kultivar cabai. J. Agrikultura 16:146152.

Womdim NR, Swai IS, Chadha ML, Selassie GK, \& Marchoux G. 2001. Occurence of Chilli veinal mottle virus in Solanum aethiopicum in Tanzania. Plant Dis. 85:801. 